\title{
E- COMMERCE: FUTURE IN INDIA
}

\author{
Bijender Singh
}

Abstract- Many economists and experts believe that in recent years, a revolution has occurred similar to the industrial revolution which the world has entered the information age. It makes large changes in the economic, social and cultural aspects. One aspect of this transformation is changes in economic relations between individuals, corporations and governments. Commercial exchange between people who had been based on paper documents to transactions of by us the systems based on electronic information. In this article we will discuss the benefits of e-commerce and its impact on the market.

\section{INTRODUCTION}

E-commerce has so many advantages in our life because it makes convenient in daily life of the people. Several explanations have been proposed for e-commerce that most of them are based on past experiences in the use of e-commerce. As with ecommerce, e-business also has a number of different definitions and is used in a number of different contexts. One of the first to use the term was IBM, in October 1997, when it launched a campaign built around e-business. Today, major corporations are rethinking their businesses in terms of the Internet and its new culture and capabilities and this is what some see as ebusiness. There is no one commonly agreed definition of e-commerce or e-business. Thus, there is a need to clarify terms being used and explain the context in which they are being applied. E-commerce has an impact on three major stakeholders, namely society, organizations and customers. There are a number of advantages, which include cost savings, increased efficiency, customization and global marketplaces. There are also limitations arising from e-commerce which apply to each of the stakeholders. In order to understand electronic commerce it is important to identify the different terms that are used, and to assess their origin and usage.

\section{CONCEPTS AND DEFINITIONS}

Electronic commerce or e-commerce refers to a wide range of online business activities for products and services. It also pertains to "any form of business transaction in which the parties interact electronically rather than by physical exchanges or direct physical contact." A more complete definition is: E-commerce is the use of electronic communications and digital information processing technology in business transactions to create, transform, and redefine relationships for value creation between or among organizations, and between organizations.

\section{E-COMMERCE IN INDIA}

For developing countries like India, e-commerce offers considerable opportunity. Ecommerce in India is still in growing stage, but even the most-pessimistic projections indicate a boom. It is believed that low cost of personal computers, a growing installed base for Internet use, and an increasingly competitive Internet Service Provider (ISP) market will help fuel e-commerce growth in Asia's second most populous nation. The first e-commerce site in India was rediff.com. It was one of the most trafficked portals for both Indian and nonresidents Indians. It provided a wealth of Indian-related business news a reach engine, ecommerce and web solution services. The past 2 years have seen a rise in the number of companies enabling e-commerce technologies and the internet in India. Major Indian portal sites have also shifted towards e-commerce instead of depending on advertising revenues. The web communities built around these portal sites with content have been effectively targeted to sell everything from event and mouse tickets the grocery and computers. The major in this services being Rediff.com and the net and India plaza with started a shopping section after In spite of RBI regulation low internet usage ecommerce sites have popped up everywhere hawking things like groceries, bakery items, gifts, books, audio and video cassettes, computer etc. none of the major players have been deterred by the low PC penetration and credit card.

\section{FUTURE OF E-COMMERCE IN INDIA}

India is developing rapidly and if development is to be measured, how can we ignore the role of e commerce in it. The internet user base in India might still be a mere 100 million which is much less when compared to its penetration in the US or 
UK but it's surely expanding at an alarming rate. The number of new entrants in this sphere is escalating daily and with growth rate reaching its zenith it can be presumed that in years to come, customary retailers will feel the need to switch to online business. Insights into increasing demand for broadband services, rising standards of living, availability of wider product ranges, reduced prices and busy lifestyles reveal this fact more prominently thereby giving way to online deals on gift vouchers. Going by the statistics, the E commerce market in India was worth about $\$ 2.5$ billion in 2009 . It rose to $\$ 8.5$ billion by 2011 thus depicting a definite surge in the last two years. According to a statement released by the Internet and Mobile Association of India (IAMAI), these figures would reach up to $\$ 12$ billion by 2012 ! To understand this scenario, we can divide E-commerce into three broad categories which include physical services, physical goods and virtual goods.

\section{Essential factors for growth of E-Commerce in India:}

$>$ Customer convenience: By providing Cash on delivery payment option service to Customers.

$>$ Replacement guarantee: Should be Offers 30 day replacement guarantee to their customers.

$>$ Reach: Enabling mobile-capable sites and supporting M-Commerce services.

$>$ Location based services: Since customers these days are always on the move, promoting the right product at the right time and location becomes an integral aspect

$>$ Multiple payment option: standard credit cards, debit cards and bank payments option should be there.

$>$ Right content: Getting the right content and targeting customers with crisp and Relevant information is of utmost importance to users on the move.

> International Journal of Computing \& Business Research ISSN (Online): 2229-6166 Proceedings of 'I-Society 2012' at GKU, Talwandi Sabo Bathinda (Punjab)

$>$ Price comparison: Providers offering instant price comparison are highly popular Amongst the price conscious customers.

$>$ Shipment option: Low cost shipment should be there. The convenience of collecting orders post work while returning home should be there.

$>$ Logistical challenges: In India, the geographical spread throws logistical challenges. The kind of products being offered by providers should determine the logistics planning.

Legal challenges: There should be legal requirement of generating invoices for online transactions.

$>$ Quick Service: Timely service provided by the company.

$>$ Terms and condition: $\mathrm{T} \& \mathrm{C}$ should be clear \& realistic.

$>$ Quality: The product quality should be same as shown on the portal.

$>$ Customer care centre: A dedicated 24/7 customer care centre should be there.

\section{CONCLUSION}

The future of E-Commerce is difficult to predict. There are various segments that would grow in the future like: Travel and Tourism, electronic appliances, hardware products and apparel. There are also some essential factors which will significantly contribute to the boom of the Ecommerce industry in India i.e. replacement guarantee, M-Commerce services, location based services, multiple payment option, right content, shipment option, legal requirement of generating invoices for online transactions, quick Service, T \& C should be clear \& realistic, the product quality should be same as shown on the portal, dedicated 24/7 customer care centre should be there. We found various types of opportunities for retailers, wholesalers/distributors, producers and also for people. Retailers meet electronic orders and should be in touch with the consumers all the time. Wholesalers can take advantage of Ecommerce who are capable of establishing contractors with reputed producers and linking their business with the on- line. Producers can also linking themselves with on-line, by giving better information about their products to the other links in the business chain and by a having a brand identity. As more people are getting linked with E-commerce, the demand for centre providing internet facility or cyber cafe is also increasing.

\section{REFERENCES:}

[1] Bansal, Rashmi, Growth of the Electronic Commerce in China and India: A Comparative Study

[2] Dubey Rahul, E-Commerce poised for a leap in 2012

[3] Emmanuel Lallana, Rudy Quimbo, Zorayda Ruth Andam, ePrimer: An Introduction to eCommerce, 2000), 2

[4] Ernest A. Capozzoli, Thomas K. Pritchett, E Commerce: A Conceptual framework, Journal of Asia-Pacific

[5] Business Kaur Pradeep, Dr. Joshi Mukesh, E-Commerce in India: A Review, IJCST Vo 1. 3, issue 1, 2012

[6] Kaur, Ramneet, E-Commerce in India, Asian journal of research in business economics and management, vol. 2, issue 6, 2012

[7] MK, Euro Info Correspondence Centre (Belgrade, Serbia), "E-commerce-Factor of Economic Growth."

[8] Rosen, Anita, The E-commerce Question and Answer Book (USA: American Management Association, 2000$), 5$.

[9] Sharma Shweta, Mittal,Sugandha, "Prospects of E-Commerce in India". 


\section{Websites}

- E-Commerce Guide.Com

- E-Commerce Times

- www.business.com

- www.forrester.com

- www.iamai.in 